This is a pre-print version of an article that has been published in Popular Music and Society. The published version can be downloaded from:

http://www.tandfonline.com/doi/full/10.1080/03007766.2015.1061344

Please cite this article as:

Hoeven, A. van der, Janssen, S., \& Driessen, S. (2016). Articulations of Identity and Distinction: The Meanings of Language in Dutch Popular Music. Popular Music and Society, 39(1), 43-58. http://doi.org/10.1080/03007766.2015.1061344

\title{
Articulations of Identity and Distinction: The Meanings of Language in Dutch Popular Music
}

Arno van der Hoeven, Susanne Janssen and Simone Driessen

\begin{abstract}
On the basis of interviews with music audiences, heritage practitioners, and cultural industry workers, this article explores how language use in Dutch popular music relates to local and historically situated taste patterns and music practices. Most popular music in the Netherlands is sung in English, Dutch, or dialects of the Dutch language. We discuss how these languages are used in Dutch popular music as an expression of cultural taste, cultural identities, and local heritages. Furthermore, we describe historical trends in the attention to various languages and their associated genres, focusing on processes of classification and cultural legitimization.
\end{abstract}




\section{Introduction}

This article concerns the role of language in Dutch popular music. Both language and popular music are markers of national and local identity (Larkey; Bennett, Popular Music). According to Dutch sociologist Abram de Swaan, the competition between the "super-central" English language and the more peripheral domestic languages causes cultural producers to face a choice between two options. On the global market for cultural products (and languages), they can choose between "being a small fish in a big pond or a big fish in a small pond" (De Swaan 21). To put it succinctly, when Dutch musicians sing in their native language, they limit their potential audience and their chances of success abroad (Verboord and Brandellero).

However, despite the dominance of the English language in international communication and entertainment, the popularity of music sung in Dutch has not decreased. On the contrary, as in other European countries, the popularity of domestic music and music in the native language has grown in recent decades (Achterberg et al.; Bekhuis, Lubbers, and Ultee; Mutsaers, "De Nederlandse taal"). Nevertheless, foreign music still dominates the charts in the Netherlands. Generally, Dutch popular music is performed by artists singing in English, Dutch, or one of the several dialects of the standard language. The Netherlands has various local dialects, of which Frisian is officially recognized as a minority language (Grijp). As will become clear in this study, the languages in which Dutch popular music is sung are historically associated with specific music genres and locally situated modes of musical consumption. 
This article provides insight into the relationship between the words of songs, taste patterns, and the ways in which languages of popular music constitute local communities (Frith). Bennett ("Hip Hop" 82) notes there is much literature on popular music lyrics, although "rather less attention has been focused upon the cultural significance of the language in which they are sung." Therefore, we examine how meanings attached to language in Dutch popular music can be understood against the background of locally and historically situated patterns of music production and consumption. Music is a form of communication in which the meanings conveyed through lyrics are received by people in specific sociocultural settings (Marc). How people appropriate the "verbal messages" (Marc) of music_if they pay attention to lyrics at all—depends on their cultural capital and the local context in which music is consumed.

In this article, we first discuss literature on genre, musical taste, and cultural legitimization. Second, we discuss the methodological aspects of this study. Third, we present an overview of historical trends in language use in Dutch popular music. Finally, on the basis of an analysis of interviews with music audiences, cultural industry workers, and heritage practitioners, we discuss how language in the field of popular music in the Netherlands is associated with articulations of taste, identity, and sense of place.

\section{Theorizing Genres and Patterns of Music Taste}

In this section, we discuss how the connections among genres, their cultural legitimacy, and patterns of music taste have been conceptualized in the existing literature and relate to sociocultural changes in society. This serves as a theoretical background for the analysis of language use in Dutch popular music. 


\section{Musical and Societal Developments}

The past four decades have witnessed the decline of the strong distinction between "high" and "popular" culture and the increased legitimacy of popular cultural products and genres, which have been embraced by members of higher-status groups in society as well as institutions and experts in the cultural field. Since the 1970s, popular music in particular has clearly gained in cultural legitimacy, as evidenced by, among other things, its increased coverage in the cultural sections of elite newspapers (Janssen, Verboord, and Kuipers, "Comparing"), the rise of specialized popular music outlets and experts, and the inclusion of popular music in cultural policies, heritage institutions (Brandellero and Janssen), and educational curricula (Bevers).

These developments are intimately connected to changes in social structure (DiMaggio) and processes of individualization and globalization (Janssen, Verboord, and Kuipers, "Comparing"). The democratization of higher education, the emancipation of disadvantaged groups (women; youth; ethnic, racial, and sexual minorities), increased social mobility, and heterogeneity have contributed to the erosion of traditional cultural hierarchies and enabled socially mobile people and minorities to "import" their tastes into higher circles and to bestow prestige upon their preferred genres. Processes of individualization have made people less prone to subscribe to traditional cultural hierarchies and collective taste patterns, but, instead, increasingly require them to choose individually and to show individual "authenticity" in their expression of taste. Last but not least, greatly improved dissemination technologies, an increase in shared languages and multilingualism, and the rise of cultural multinationals have led to a cultural world system, in which national cultural fields have become 
embedded in transnational systems of exchange, influence, and competition. Musical supply, has, correspondingly, been fundamentally altered as well. Not only has it become much larger and more diversified than ever before, but, in many places in the world, national music production competes with foreign imports and domestic music is just one possible option among many.

\section{Music, Identity, and Community}

Numerous studies have illuminated how music is deeply embedded in social life and how music signals and shapes the identity of individuals as well as collectivities. De Nora conceives of music as a "technology of the self" and demonstrates how individuals build an identity by using music to signify important events and relations in their lives and to guide a variety of activities in everyday life.

Music is also used by groups as a means to establish an identity. People may signal their group membership to others-inside and outside the group - by embracing certain artists or genres. Music thus also serves as a "technology of the collective" (Roy and Dowd) because people are drawn to like-minded individuals who share common ground in their aesthetic perceptions, expressive forms, and cultural practices. This role for music has become increasingly salient in recent times, because people can potentially belong to many different groups (DiMaggio).

A growing body of research addresses the development of "music scenes" that gather around specific music genres (Bennett, "Consolidating"), revealing huge differences among such collectivities, in terms of their stability/fluidity as well as their geographical and social reach. Whereas 
some scenes are firmly rooted in specific localities (Bennett, "Consolidating"), others develop virtual spaces (Beer) connecting individuals from across the globe (Regev).

Various authors have highlighted the gradual formation of a "transnational cosmopolitan culture" or a "world culture" (Hannerz; Urry), involving the emergence of a cultural or aesthetic cosmopolitanism (Regev), which can be defined as "a cultural disposition involving an intellectual and aesthetic stance of 'openness' towards peoples, places, and experiences from different cultures, especially those from different 'nations"' (Szerszynski and Urry 468).

On the other hand, in the face of rapidly advancing internationalization and globalization, people can symbolically express their national, regional, or local identities through the consumption of domestic music or other "homegrown" cultural goods, which may "constitute national sensibilities, embody national pride, [and] negotiate national meanings" (Fox and Miller-Idriss 551).

Although, for almost half a century, foreign (Anglo-Saxon) music has dominated the charts (Bekhuis, Lubbers, and Ultee; Verboord and Brandellero) as well as the critical coverage given to popular music (Janssen, Verboord, and Kuipers, "Cultural") in the Netherlands and other European countries, domestic music and music in the native language has gained in popularity and prestige in the 1990s and 2000s (Achterberg et al.; Bekhuis, Lubbers, and Ultee; Mutsaers, "De Nederlandse taal"). National pride in a country proves to be related to the popularity of songs in the native language (Bekhuis, Lubbers, and Ultee), while the international 
success of songs (Verboord and Brandellero) is affected by language as an aspect of cultural proximity.

Instead of connecting individuals, groups, or cultures, musical tastes can also enhance social divisions, as groups may deploy music to demarcate themselves from others (Bourdieu; Roy). Members of subcultures may deliberately use music to articulate their social stance in opposition to the political establishment or cultural mainstream (Bennett, "Consolidating"). More often, however, such symbolic distinction seems to occur in an unintentional fashion, as people's social background and associated cultural capital have been found to shape their musical preferences and modes of listening, with this "musical habitus" appearing as natural (Bourdieu; Rimmer).

While Bourdieu's data led him to conclude that "nothing more clearly affirms one's 'class', nothing more infallibly classifies, than tastes in music," (10) more recent studies show that in France (Coulangeon and Lemel) as well as other Western countries the more highly educated have traded some of their consumption of "highbrow" art forms for more popular ones, thus becoming more "omnivorous" (DiMaggio and Mukthar; Peterson and Kern; Van Rees, Vermunt, and Verboord; Van Eijck and Lievens). A vast body of research indicates that socially privileged music listeners do not draw strong boundaries between the high and the popular. People with high educational attainment and occupational prestige also appear to engage with a wide range of musical genres liked by less advantaged groups (van Eijck, "Social"). Such omnivorous musical consumption suggests that the alignment between social stratification and 
musical tastes is less straightforward than before (Garcia-Alvarez, KatzGerro, and Lopez-Sintas).

\section{Patterns of Musical Taste}

However, the emergence of more inclusive taste patterns does not flag the dissolution of social stratification/classification in music. Rather, these more "open," omnivorous, or cosmopolitan tastes seem to constitute a new form of (multi-)cultural capital that the socially privileged can use in highly individualized ways (Ollivier; Meuleman and Savage; Warde, Wright, and Gayo-Cal).Van Eijck and Lievens discern different types of cultural omnivores, who combine elements from the highbrow, pop, and folk "cultural schemes". These schemes, and their various combinations, correspond to different value orientations pertaining to social integration (236). In a study of cosmopolitan tastes, Meuleman and Savage find that the more highly educated tend to prefer a combination of Dutch and foreign culture: "To simply have a taste for national cultural forms is hence associated with those lacking any cultural capital" (240). As a manifestation of cosmopolitan taste (Cheyne and Binder; Regev), listening to international artists and music in a foreign language can be a marker of distinction for people in higher social strata.

In line with this, the engagement of more highly educated consumers or cultural experts with popular music products does not imply that all popular music genres have been consecrated as legitimate culture or enjoy similar degrees of recognition or prestige. New hierarchies have emerged within popular music and other art forms that were previously simply considered "popular" (Baumann; Janssen, Verboord, and Kuipers, "Comparing"). Some musical genres in particular have come to be regarded as more 
sophisticated or "highbrow" (Bryson; Schmutz et al.). Schmutz and colleagues find that the increasing prominence of popular music in European and US elite newspapers clearly privileges some genres over others. Even though these papers have become more eclectic over time and cover a wider range of musical genres, heavy metal in US and German newspapers and hip hop in Germany and France are notably absent or limited in their coverage.

These studies demonstrate that genre distinctions are not purely aesthetic decisions, but socially enabled and socially constructed events that classify musical products as well as the people engaging with these products. Therefore, we conceive of music genres as dynamic entities, with evolving, rather than fixed, meanings and connotations that shift over time (Lena and Peterson). Furthermore, from this literature review it follows that the consumption and valuation of musical genres should be examined in relation to socially rooted taste patterns. The meanings and values that people attach to specific music genres are contingent upon social position, cultural capital (Rimmer), place (Bennett, Popular Music; Cheyne and Binder), and national, regional, or local ties, but also on personal biographies (De Nora) and value orientations (Van Eijck and Lievens).

Although many studies have examined the relationship among Dutch music genres, taste patterns, and processes of cultural legitimization, the existing studies rarely address the sociocultural meanings attached to language use in popular music. However, as Larkey argues, "genres provide musical and cultural contexts, frames for the social and cultural positioning of the lyric message as well as the mood and the attitude transmitted by the lyrics" (1617). Therefore, we consider how language in Dutch popular music relates 
to locally and historically situated patterns of music production and consumption. We move beyond a focus on taste preferences, by studying music consumption and language use in popular music as contextualized cultural practices (Rimmer).

\section{Background to the Study}

The research for this article has been conducted in the context of the European project "Popular Music Heritage, Cultural Memory and Cultural Identity."This project examines popular music's connections to local understandings of identity and cultural heritage. For this article, we analyzed a subset of a total of 24 in-depth interviews. The interviews selected for this subset relate to language use in popular music as well as cultural taste patterns. These interviewees were primarily approached via social media, through snowball sampling or by contacting organizations involved in music heritage. The qualitative character of the data enables us to contextualize music tastes (Rimmer) by exploring the meanings people attach to language in popular music, how they use music in their everyday lives, and which music practices are associated with those uses. Thus, we study the relationship between language and music in its local and social context.

Our analysis is based on interviews with people from various parts of the Netherlands (i.e. urban and rural settings). We aimed for variation in the sample, to explore the different ways in which popular music is related to language in the Netherlands. The sample consists of people who have a more "casual" engagement with music, as well as dedicated music fans and "amateur experts" (Baym and Burnett) participating in music heritage 
initiatives. These people come from different socioeconomic backgrounds and their musical preferences range from Dutch language schlagers to indie music. Six people have or have had paid positions in the cultural industries, for example as a music journalist or professional musician. All interviews are analyzed using TAMS and ATLAS. ti. The authors coded one another's interviews to explore patterns in the data. The quotations used in this article have been translated from Dutch to English.

In addition to the interviews, we conducted a literature review. We collated academic studies and popular publications on Dutch popular music history, language, and dialect use in music. To this end, we followed the definition of popular music as a commercial cultural form which relies on the music industry and mass media for its production and distribution (Shuker). The selection of material was limited to the literature dealing with the period from the late 1950s onwards. Generally, the song "Rock Little Baby of Mine" by the Tielman Brothers (1958) is canonized as the first Dutch rock and roll single and the starting point of popular music in the Netherlands (Van der Plas). "Kom van dat Dak af" by Peter Koelewijn (1960) is considered the first Dutch-language rock and roll song. In the next section, we present an overview of the role of language in Dutch popular music history based on the literature review.

\section{Language and Genre in Dutch Popular Music History}

Throughout the history of Dutch popular music, most artists have sung in English, Dutch, or dialects of the standard language. However, the popularity of music sung in these languages has fluctuated over the years. In line with our conception of genres as dynamic entities that structure processes of music consumption and production, we give an overview of 
such developments through an examination of the genres associated with different musical uses of language. We will focus on broad trends in the popularity of Dutch music specifically. As concerns music from foreign artists, the tastes of Dutch audiences largely follow international trends (Schuyt and Taverne).

The genre most commonly associated with singing in Dutch is the so-called levensliederen, which could be loosely translated as "songs of life" (De Bruin and Grijp). These sentimental songs generally have simple arrangements and are easy to sing along to; their straightforward lyrics deal with topics such as love and death. These songs are often derisively referred to as "smartlappen" (i.e. tearjerkers), because of their sentimentality and "lowbrow image" (De Bruin and Grijp). For this reason, the attention to levensliederen by media and record labels has varied over the years, even though this genre has remained popular with a large audience throughout the history of Dutch popular music. Another constant presence in Dutch music history, although critical interest in this genre has declined in recent decades (Schmutz et al.), is the Dutch-language songs of comedians and stage performers who took their inspiration from French chansons (Kloters).

In the 1960s and '70s, rock and beat music sung in English became very popular (Van der Plas). Following on from the popularity of the Beatles and the Rolling Stones, Dutch bands such as the Golden Earring, the Outsiders, Q65, and Shocking Blue brought an international sound, sometimes leading to chart successes abroad. Dutch-language music was an aberration at the time, because both bands and audiences closely followed British and 
American trends in music and youth culture (Schuyt and Taverne; Van der Plas).

It was only in the early 1980s that rock and pop music sung in Dutch achieved a widespread mainstream appeal in the Netherlands and became “accepted" (Schuyt and Taverne; Van Elderen). The success of Doe Maar's music, a cheery mix of punk and reggae, stimulated other bands like Het Goede Doel, Toontje Lager, and the Frank Boeijen Groep to make Dutchlanguage music. According to Schuyt and Taverne, "Doe Maar had proven that pop or rock did not necessarily have to be in English, nor be typically American" (418). Tellingly, Doe Maar's first album came out on Telstar, a record label that is specialized in the schmaltzy levensliederen. Other labels were initially reluctant to work with Dutch-language artists, because, even if musicians operated in other genres, they were associated with what the record industry (Hitters and van de Kamp; Rutten, Dekkers, and Jansen; Van der Plas) and music critics (Schmutz et al.) dismissed as "lowbrow" levensliederen. Nevertheless, bands like Doe Maar successfully demonstrated how pop and rock music can be combined with Dutch lyrics (Schuyt and Taverne). However, after the break-up of this band in 1984, the market share of domestic music significantly declined again (Rutten; Rutten, Dekkers, and Jansen).

In the 1990s, the tide turned for Dutch artists. Research on music charts shows that, as in many other European countries, the popularity of domestic popular music and music sung in the native language was increasing in this period (Achterberg et al.; Bekhuis, Lubbers, and Ultee; Rutten, Dekkers, and Jansen; Van de Kamp). Explanations given for this are the declining success of major international stars, the advent of independent record 
labels, the improved quality of Dutch musical productions (Rutten, Dekkers, and Jansen), and the wider availability of technologies for producing and distributing music (Achterberg et al.; Grijp). Furthermore, new commercial television and radio stations enhanced the promotion of Dutch music (Mutsaers, "De Nederlandse taal"), such as the Dutchlanguage songs of "middle-of-the-road artist" Marco Borsato (Hitters and Van de Kamp; Rutten, Dekkers, and Jansen). Artists singing in dialects of the Dutch language profited from the many local radio stations, which used this genre to give form to their local profile (Grijp). The band Normaal had already been successful with dialect rock in the late 1970s, but in the 1990s they were joined by other dialect bands like Rowwen He'ze and Skik. The popularity of this regionally conscious genre has been characterized as a dialect renaissance (Grijp). Even though the number of people speaking dialects is actually declining and some of these dialects are converging into regiolects (i.e. a blend of various dialects), the success of dialect music indicates a renewed interest in dialect and its significance for local identities (Goeman and Jongenburger). Furthermore, in the 1990s, Dutch hip-hop acts began to rap in Dutch (Wermuth), often incorporating slang, neologisms, and creative adaptations of English words in their lyrics. For Dutch youth and minority groups, this genre developed into a vital musical form to express themselves and address societal issues (Mutsaers, "De doorbraak"), and as such also gained critical recognition (Schmutz et al.).

In the 2000s, artists singing in both Dutch and English have consolidated their positions. Many female singer-songwriters switched from English to Dutch lyrics in this period (De Vrieze). However, as in the years before, acts with an "alternative orientation" (e.g. rock, metal, and indie bands) generally opt for English lyrics. In post-9/11 society, Dutch-language hip 
hop developed into a platform where social tensions are articulated (Mutsaers, "De doorbraak"). Artists singing the traditional Dutch language levensliederen, who used to be neglected by public media, achieved more mainstream popularity and recognition in the 2000s (De Bruin and Grijp). In 2010, an annual conference and festival was established for people working in the field of Dutch-language music (see http://www. bumanlmuziekfestival.nl/). Furthermore, new radio (e.g. 100\% NL) and television (e.g. TV Oranje) channels focusing on Dutch-language music began broadcasting. However, Dutch elite newspapers still give relatively more space to popular music genres such as rap and electronica than to levensliederen and the "Dutch chansons" (i.e. kleinkunst). This suggests that the latter genres "remain outside the purview of the elite newspapers and their legitimating power" (Schmutz et al. 510). The most internationally successful artists in the second half of the 2000s are DJs such as DJ Tie"sto and Armin van Buuren. The scarcity of lyrics in dance music means there is no language barrier for them.

\section{Articulations of Taste and Personal Identity}

In this section, we examine why Dutch audiences prefer music sung in a particular language. As discussed above, the genres associated with various languages are subject to processes of cultural legitimization. We saw that media and music industries classify and evaluate music. Alternative rock music sung in English, for example, has more artistic legitimacy than the Dutch levensliederen.

On a personal level, the appreciation of language in music is constituted by the musical habitus (Rimmer). Building on Bourdieu's concept of the 
habitus, Rimmer emphasizes the connections among people's social position, music practices, and cultural capital endowments. The following quotes demonstrate how preferences for music sung in specific languages are shaped by the musical habitus. The first respondent distances himself from Dutch language music, while the second respondent experiences such dispositions as a taboo on listening to these genres.

I: I would now like to discuss music in relation to place. You said you grew up in Drenthe; do you ever listen to music from Drenthe? R1: No, never. No, no. Well, of course you grow up with this music, but it is not what we listened to at home. So you know it because you live there, but it is very folkish music actually. It's okay for people who like it, but you won't find it in my record collection. (Male, age 42, communications adviser)

R2: It seems like a taboo in the Netherlands. If you like Dutchlanguage music, you don't belong. I don't know how to explain this. Well lately ...

R3: It is getting better..

R2: ... things are changing for the better, fortunately. I live in the Netherlands, that's how I see it. In England they also have only English-singing artists. And take France. (Male and female, founders of online radio station)

In the first quotation, the respondent refers to the influence of the music played in his parents' home on his own music taste. As Rimmer argues, primary socialization is very important in the formation of the musical habitus. In secondary socialization, education, peers, and media further shape musical tastes. The appreciation of certain genres and associated 
languages correlates with people's cultural capital and educational attainment (Van Eijck, "Social"). The second respondent observes an increased legitimacy of levensliederen, which is in line with the developments discussed in the previous section. Generally, however, the engagement of more highly educated people with this genre often involves a certain camp sensibility (De Bruin and Grijp). According to Hitters and Van de Kamp, "Since the start of the new millennium, 'volks' has become a more accepted, albeit sometimes 'camp,' addition to the public's increasingly 'omnivorous' tastes that, among other things, involve high status individuals engaging in low status musical genres" (475). Nevertheless, the exclusive consumption of national music correlates with having lower levels of cultural capital (Meuleman and Savage). More highly educated people tend to prefer a combination of Dutch and foreign cultural products.

However, music in the Dutch language, or one of its dialects, is more accessible than foreign music, particularly for those who are less competent in the English language (Marc). "I'm not a specialist in English lyrics," explains one respondent (male, age 47, sales manager). When music is in the native language of the audience, it enhances the communication between musicians and listeners (Bennett, "Hip Hop"; Marc). It allows people to identify with the lyrics and the way these resonate with their biographical experiences. As Frith argues, the words of songs carry meanings and are signs of emotion and character. People connect songs to autobiographical memories that form their identities (De Nora; Van Dijck). The next respondent first expresses awareness of the low artistic legitimacy of levensliederen and then explains what these songs mean to him and how they evoke personal experiences. 
R: A lot of people say they don't like levensliederen. I also don't like every smartlap (i.e. tearjerker); but if you start listening to the lyrics, you notice there is some truth in it. That makes the record better. ...

I: Could you tell me something about what you find in the lyrics?

R: Often it's about things you have experienced yourself. For example, people who passed away are often sung about. The songs then bring back those feelings. (Male, 33, DJ of an online radio station)

So far, we have focused on the relationship among language in music, personal tastes, and biographical experiences. However, particularly in the case of Dutch dialects, there are also strong connections between music and place.

\section{A Sense of Place and Community}

In this section we examine how language relates to a sense of place and community. Whereas the previous section discussed language and music appreciation on a personal level, we now turn to a collective sense of language and negotiations of geographical distinction. As Wallis and Malm argue, "together with language, music seems to play a decisive role in the formation of the identity of individuals and their feelings of belonging to a group" (43).

Language constitutes connections between music and place. Particular genres, and the languages in which they are sung, have become associated with specific localities. An example of this is the so-called "pirate music," 
which refers to levensliederen of lesser-known artists (Van der Hoeven). Because the Dutch-language levensliederen used to be neglected by national media (De Bruin and Grijp), many illegal radio stations began broadcasting this music from the 1970s onwards. Nowadays, this interest in music with a regional popularity such as dialect music (Grijp) is largely catered for by legal commercial and public radio stations. However, particularly in the more rural eastern and northern provinces, pirate radio stations are still active, despite increasing fines by the Radio Communications Agency (Van der Hoeven). Here it has become a local tradition to use radio frequencies illegally to broadcast "pirate music" for local audiences. The next quotation, about a respondent's musical experience at a construction site in the "west," illustrates that the genres associated with these practices are more popular in rural regions.

You did not need to put on a pirate station there, and then they immediately said: put something different on, you peasant, or else we'll throw your radio off the scaffold. [Laughs] But if you're here in Drenthe [eastern province], you should not say that, for they'll throw the western guy off the scaffold instead of the radio.

(Male, 59, former pirate/editor of a pirate website)

This demonstrates how music relates closely to one's regional identity and can be a marker of geographical distinction. As Frith argues, popular music's "cultural (and commercial) purpose is to put together an audience, to construct a sense of 'us' and 'them"' (91). Likewise, in the Limburg province of the Netherlands a collective identity is constructed through singing in dialect. For the Limburgians, speaking or understanding dialect is part of their regional identity and contributes significantly to the sense of community in this region (Belemans). A large majority of the Limburgian 
inhabitants use one of the local dialects on a regular basis (Belemans; Goeman and Jongenburger). Accordingly, this region has a rich heritage of dialect songs, often written for the annual carnival festival, a festive fourday event with roots in Catholicism. Grijp argues that, for musicians, singing in the language of their roots is the most effective way of expressing themselves. Analyzing the language choices of musicians, he finds that "although they have a good command of English, they themselves do not feel that this helps them to get to the heart of things when they write lyrics" (235). Moreover, when music is in the native language or in dialect, it enhances feelings of local pride and cohesion. As an interviewee from Limburg (male, 36, manager) illustrates, "If you hear that dialect [in songs], you immediately think of Limburg."

Through the inclusion of local elements, popular music genres are localized. This is demonstrated by the respondents' negotiations about the importance of dialect in songs. A 24-year-old Limburgian respondent (male, student) considers dialect to be particularly of added value when it suits the song, as when the song already contains some elements reminding him of the region. Otherwise, it could also be sung in English, he argues. What are perceived as unique local genres are often appropriations of foreign music styles (Bennett, Popular Music), to which local elements such as the dialect are added. This makes them emblematic examples of glocalization. According to Grijp, "we can interpret dialect music as a special form of glocalisation - an attempt to preserve the local culture, in this case, the local or regional language, by combining it with global music styles" (241). For a female call center agent (24), the dialect forms the main signifier of what makes music typical "Limburgian music," since "lots of dialects from other regions are just degenerations of Dutch. Limburgian is 
quite a different language." This shows how existing genres are reworked in local sociocultural settings through the addition of distinctive musical and lyrical traits.

As Grijp observes, these local meanings are often formed through subjects with a "regional flavor" (235). For example, local references in lyrics can elicit shared memories, values, or lifestyles. According to Van Dijck, "Through collective experiences, embedded in social practices and cultural forms ... people construct collective reservoirs of recorded music that "stick to the mind' and, in terms of collectivity, become our cultural heritage." Language forms a key resource in the "production of place" (Cohen). Through music sung in specific languages, local identities are constructed, preserved, and affirmed.

\section{Conclusions and Discussion}

In this article, we have explored how the meanings attached to language in Dutch popular music can be understood against the background of locally and historically situated patterns of music production and consumption. To this end, we focused on the genres associated with the main languages in the field of Dutch popular music. We conceived of genres as dynamic entities that classify music and, in their relation to cultural taste and identity, the people listening to those genres. These processes of classification, and thus the ways in which various genres and their associated languages are produced and consumed, are contingent upon musical and societal developments. New genres such as Dutch hip hop and dialect rock have emerged, popular music has achieved a growing cultural legitimacy, and, accordingly, the media have increased their coverage of 
popular music through a growing number of media outlets (e.g. digital television and radio).

Following these developments in the last few decades, the Dutch language has become more accepted as a form of musical expression and has consolidated its position in the national field of popular music. It is now used in a wide range of genres (e.g. rap, levensliederen, middle-of-theroad), which in many cases have their own specific festivals, media, and record labels. Nevertheless, English-language music still dominates the charts. Moreover, some Dutch-language genres have achieved more cultural legitimacy than others. In the case of the schmaltzy levensliederen, for example, the engagement of higher social strata with this genre is generally not genuine, but rather based on an ironic sensibility (Van Eijck, "Culturele leefstijlen"; Hitters and Van de Kamp). This demonstrates that the same genre can have different meanings for various sociocultural groups. Furthermore, it highlights the need for research which moves beyond an exclusive focus on what is consumed to how patterns of music consumption can be understood in different sociocultural contexts (Van Eijck, "Culturele leefstijlen"). Our research demonstrates that language is an important aspect of these ways in which music is classified and consumed in the Netherlands.

Finally, we would like to discuss our findings on language in Dutch popular music in relation to debates on the globalization of music. In recent years, several researchers have examined how globalization affects the field of popular music through the analysis of charts. These studies found that national pride in a country is related to the popularity of songs in the native language (Bekhuis, Lubbers, and Ultee) and, as an aspect of cultural 
proximity, language influences the potential international success of songs (Verboord and Brandellero). We have contributed to this knowledge by highlighting how language is used in the local reception of global genres and in the expression of identities and cultural tastes. While listening to particular Englishlanguage music could signify a cosmopolitan taste for

some audiences (Meuleman and Savage), other genres are rooted more strongly in local communities and heritages. Music sung in dialect gives shape to local identities and fosters a sense of community. Furthermore, through lyrics in the native language, global genres are localized. This is in line with the finding of Meuleman and Savage that "rather than national fields being simply eclipsed by transnational fields, they coexist with differing degrees of salience for specific social groups and across various cultural domains" (243). As Larkey argues, language choices in popular music are bound up with the changing global-local nexus. Through language, articulations of taste, memory, and identity are negotiated. For these reasons, language in popular music is situated at the junction between past and present and the local and global.

\section{Acknowledgements}

This research has been supported as part of the Popular Music Heritage, Cultural Memory and Cultural Identity (POPID) project by the HERA Joint Research Program (www.heranet.info), which is co-funded by AHRC, AKA, DASTI, ETF, FNR, FWF, HAZU, IRCHSS, MHEST, NWO, RANNIS, RCN, VR, and the European Community FP7 2007-13, under the "Socio-economic Sciences and Humanities" program. 


\section{Literature}

Achterberg, Peter, Johan Heilbron, Dick Houtman, and Stef Aupers. “A Cultural Globalization of Popular Music? American, Dutch, French, and German Popular Music Charts (1965 to 2006)." American Behavioral Scientist 55 (2011): 589-608. Print.

Baumann, Shyon. Hollywood Highbrow: From Entertainment to Art. Princeton, NJ: Princeton UP, 2007. Print.

Baym, Nancy and Robert Burnett. "Amateur Experts: International Fan Labour in Swedish Independent Music." International Journal of Cultural Studies 12 (2009): 433-449. Print.

Beer, David. "Making Friends with Jarvis Cocker: Music Culture in the Context of Web 2.0." Cultural Sociology 2 (2008): 222-241. Print.

Bekhuis, Hidde, Marcel Lubbers, and Wout Ultee. "A Macro-Sociological Study into the Changes in the Popularity of Domestic, European, and American Pop Music in Western Countries.” European Sociological Review (2013): Advance online publication. doi:10.1093/esr/jct028. Print.

Belemans, Rob. Eindrapport over de Limburg-enque^te. Leuven: KU Leuven-Instituut voor Naamkunde en Dialectologie, 2002. Web. 24 June 2014.

Bennett, Andy. "Consolidating the Music Scenes Perspective." Poetics 32 (2004): 223-234. Print.

5614

_ . "Hip Hop am Main: The Localization of Rap Music and Hip Hop Culture.” Media, Culture \& Society 21 (1999): 77-91. Print. - Popular Music and Youth Culture: Music, Identity and Place.

Basingstoke, Hants: Palgrave Macmillan, 2000. Print. 
Bevers, Ton. "Cultural Education and the Canon: A Comparative Analysis of the Content of Secondary School Exams for Music and Art in England, France, Germany, and the Netherlands, 1990-2004." Poetics 33 (2005): 388-416. Print.

Bourdieu, Pierre. Distinction: A Sociological Critique of the Judgement of Taste. Cambridge: Cambridge UP, 1984. Print.

Brandellero, Amanda and Susanne Janssen. "Popular Music as Cultural Heritage: Scoping Out the Field of Practice.” International Journal of Heritage Studies 20 (2014): 224-240. Print.

Bryson, Bethany. "Anything but Heavy Metal: Symbolic Exclusion and Musical Dislikes.” American Sociological Review 61 (1996): 884899. Print.

Cheyne, Andrew and Amy Binder. "Cosmopolitan Preferences: The Constitutive Role of Place in American Elite Taste for Hip-Hop Music 1991-2005.” Poetics 38 (2010): 336-364. Print.

Cohen, Sara. "Sounding Out the City: Music and the Sensuous Production of Place.” Transactions of the Institute of British Geographers 20.4 (1995): 434-446. Print.

Coulangeon, Philippe and Yannick Lemel. "Is 'Distinction' Really Outdated? Questioning the Meaning of the Omnivorization of Musical Taste in Contemporary France." Poetics 35 (2007): 93-111. Print.

De Bruin, Martine and Louis Peter Grijp. "Van levenslied tot smartlap: De doodskist van Andre' Hazes bereikt de middenstip." Een muziekgeschiedenis der Nederlanden: Een vervolg, 2000- 2005. Ed. Louis Peter Grijp. Amsterdam: Amsterdam UP-Salome’', 2006. 947953. Print.

De Nora, Tia. Music in Everyday Life. New York: Cambridge UP, 2000. Print. 
De Swaan, Abraham. Words of the World: The Global Language System. Cambridge: Polity Press, 2001. Print.

De Vrieze, Atze. "Spinvismeisjes aan de macht: Nederlandstalig is de standaard: Nieuwe singersongwriters kiezen vaak voor hun moerstaal." 3voor12, 2014. Web. 11 Feb. 2014.

DiMaggio, Paul. "Classification in Art." American Sociological Review 52 (1987): 440-455. Print.

DiMaggio, Paul and Toqir Mukthar. "Arts Participation as Cultural Capital in the United States, 1982-2002: Signs of Decline?" Poetics 32 (2004): 169-194. Print.

Fox, Jon E. and Cynthia Miller-Idriss. "Everyday Nationhood." Ethnicities 8 (2008): 536-563. Print. Frith, Simon. "Why Do Songs Have Words?" Contemporary Music Review 5 (1989): 77-96. Print.

Garc1'a-A' lvarez, Ercilia, Tally Katz-Gerro, and Jordi Lo'pez-Sintas. "Deconstructing Cultural Omnivorousness 1982-2002: Heterology in Americans' Musical Preferences.” Social Forces 86 (2007): 755-764. Print.

Goeman, Ton and Willy Jongenburger. "Dimensions and Determinants of Dialect Use in the Netherlands at the Individual and Regional Levels at the End of the Twentieth Century." International Journal of the Sociology of Language 196-97 (2009): 31-72. Print.

Grijp, Louis Peter. "Singing in Dutch Dialects: Language Choice in Music and the Dialect Renaissance.” Reframing Dutch Culture: Between Otherness and Authenticity. Ed. Peter Margry and Herman Roodenburg. Aldershot, Hants: Ashgate, 2007. 225-244. Print.

Hannerz, Ulf. Transnational Connections: Culture, People, Places. London: Routledge, 1996. Print. 
Hitters, Erik and Miriam van de Kamp. "Tune In, Fade Out: Music Companies and the Classification of Domestic Music Products in the Netherlands." Poetics 38 (2010): 461-480. Print.

Janssen, Susanne, Marc Verboord, and Giselinde Kuipers. "Comparing Cultural Classification." Ko"Iner Zeitschrift für Soziologie und Sozialpsychologie 63.51 (2011): 139-168. Print.

—. "Cultural Globalization and Arts Journalism." American Sociological Review 73 (2008): 719-740. Print.

Klo"ters, Jacques. "De muzikale dimensie van het cabaret: Toon Hermans begint een one man show met een jazzcombo." Een muziekgeschiedenis der Nederlanden. Ed. Louis Peter Grijp. Amsterdam: Amsterdam UP-Salome', 2001. 661-669. Print.

Larkey, Edward. "Just for Fun? Language Choice in German Popular Music.” Popular Music and Society 24 (2000): 1-20. Print.

Lena, Jennifer C. and Richard A. Peterson. "Types and Trajectories of Music Genres.” American Sociological Review 3 (2008): 697-718. Print.

Marc, Isabelle. "How Do We Listen to Popular Music in Europe?” Journal of European Popular Culture 4 (2013): 29-35. Print.

Meuleman, Roza and Mike Savage. "A Field Analysis of Cosmopolitan Taste: Lessons from the Netherlands." Cultural Sociology 7 (2013): 230-256. Print.

Mutsaers, Lutgard. "De doorbraak van de Marokkaans-Nederlandse hiphop." Een muziekgeschiedenis der Nederlanden: Een vervolg, 2000-2005. Ed. Louis Peter Grijp. Amsterdam: Amsterdam UPSalome', 2006. 954-959. Print. 
—_. "De Nederlandse taal in de popmuziek." Een muziekgeschiedenis der Nederlanden. Ed. Louis Peter Grijp. Amsterdam: Amsterdam UPSalome', 2001. 871-878. Print.

Ollivier, Miche'le. "Modes of Openness to Cultural Diversity: Humanist, Populist, Practical, and Indifferent." Poetics 35 (2008): 120-147. Print.

Peterson, Richard A. and Roger M. Kern. "Changing Highbrow Taste: From Snob to Omnivore.” American Sociological Review 61 (1996): 900-907. Print.

Regev, Motti. Pop-Rock Music: Aesthetic Cosmopolitanism in Late Modernity. Cambridge: Polity Press, 2013. Print.

Rimmer, Mark. "Beyond Omnivores and Univores: The Promise of a Concept of Musical Habitus.” Cultural Sociology 6 (2012): 299-318. Print.

Roy, William G. Reds, Whites, and Blues: Social Movements, Folk Music, and Race in the United States. Princeton, NJ: Princeton UP, 2010. Print.

Roy, William G. and Timothy J. Dowd. "What Is Sociological About Music?” Annual Review of Sociology 36 (2010): 183-203. Print.

Rutten, Paul. "Nederlandstalige Popmuziek: Een synthese van eigen en mondiale cultuur.” Volkskundig Bulletin 21 (1995): 277-303. Print.

Rutten, Paul, Rob Dekkers, and Hetty Jansen. "De Meeste Dromen Zijn Bedrog." Zoetermeer: Dutch Ministry of Education, Culture and Science (OCW), 1996. Print.

Schmutz, Vaughn C., Alex van Venrooij, Susanne Janssen, and Marc Verboord. "Change and Continuity in Newspaper Coverage of Popular Music since 1955: Evidence from the United States, France, 
Germany, and the Netherlands." Popular Music and Society 33 (2010): 505-515. Print.

Schuyt, Kees and Ed Taverne. Dutch Culture in a European Perspective: 1950 Prosperity and Welfare. Basingstoke, Hants: Palgrave, 2004. Print.

Shuker, Roy. Key Concepts in Popular Music. London: Routledge, 1998. Print.

Szerszynski, Bronislaw and John Urry. "Cultures of Cosmopolitanism." Sociological Review 50 (2002): 461-481. Print.

Urry, John. Global Complexity. Cambridge: Polity Press, 2003. Print.

Van de Kamp, Miriam. "Where Corporate Culture and Local Markets Meet. Music and Film Majors in the Netherlands, 1990-2005.” PhD thesis, Erasmus U Rotterdam, 2009. Print.

Van der Hoeven, Arno. "The Popular Music Heritage of the Dutch Pirates: Illegal Radio and Cultural Identity." Media, Culture \& Society 34 (2012): 927-943. Print.

Van der Plas, Jan. 50 jaar Nederpop: Een geschiedenis van de

Nederlandse popmuziek. Amsterdam: Uitgeverij Carrera, 2008.

Print.

Van Dijck, Jose'. "Record and Hold: Popular Music between Personal and Collective Memory." Critical Studies in Media Communication 23 (2006): 357-374. Print.

Van Eijck, Koen. “Culturele leefstijlen: It Ain't What You Do, It's the Way That You Do It." Inaugural lecture. Erasmus U Rotterdam, 6 June 2013. Web. 11 Feb. 2014.

_. "Social Differentiation in Musical Taste Patterns." Social Forces 79 (2001): 1163-1185. Print. 
Van Eijck, Koen and John Lievens. "Cultural Omnivorousness as a Combination of Highbrow, Pop, and Folk Elements: The Relation Between Taste Patterns and Attitudes Concerning Social Integration." Poetics 36 (2008): 217-242. Print.

Van Elderen, Louis. "Music and Meaning behind the Dykes: The New Wave of Dutch Rock Groups and Their Audiences.” Popular Music 4 (1984): 97-116. Print.

Van Rees, Kees, Jeroen Vermunt, and Marc Verboord. "Cultural Classifications Under Discussion: Latent Class Analysis of Highbrow and Lowbrow Reading." Poetics 26 (1999): 349-365. Print.

Verboord, Marc and Amanda Brandellero. "Globalisering in popmuziekhitlijsten in negen landen, 1960-2010." Tijdschrift voor Communicatiewetenschap 41 (2013): 364-386. Print.

Wallis, Roger and Krister Malm. Big Sounds from Small Peoples: The Music Industry in Small Countries. London: Constable, 1984. Print. Warde, Alan, David Wright, and Modesto Gayo-Cal. "The Omnivorous Orientation in the UK." Poetics 35 (2008): 148-165. Print.

Wermuth, Mir. "De doorbraak van rap naar het grote (jongeren)publiek." Een muziekgeschiedenis der Nederlanden. Ed. Louis Peter Grijp. Amsterdam: Amsterdam UP-Salome’, 2001. 828-833.Print. 